\title{
Spawanie laserowe rur ożebrowanych ze stali austenitycznych
}

\author{
Laser welding of finned tubes of austenitic steel
}

\section{Streszczenie}

Rury ożebrowane są głównym elementem wymienników ciepła, co znacznie zwiększa sprawność cieplną instalacji energetycznych. Zastosowanie wymienników zbudowanych ze spawanych rur ożebrowanych $\mathrm{np}$. w kotłach gazowych i odzysknicowych jako podgrzewaczy, parowników oraz przegrzewaczy powoduje wzrost wymiany ciepła o prawie $300 \%$. Zagadnienia dotyczące rur ożebrowanych spawanych laserowo nie są dotychczas zbadane i opisane w literaturze. Stąd też podjęto pracę, w której głównym celem było określenie wpływu parametrów spawania laserowego na strukturę i właściwości rur ożebrowanych.

W Energoinstal SA w Centrum Innowacyjnych Technologii Laserowych podjęto próby spawania laserowego rur ożebrowanych ze stali austenitycznych 304 i 304H. W artykule opisano automatyczną linię technologiczną wyposażona w laser dyskowy firmy Trumph oraz układ technologiczny produkcji rur. Do oceny jakości złączy spawanych laserowo wykonano badania metalograficzne, pomiary twardości oraz technologiczną próbę odrywania żebra. Wyniki tych badań potwierdziły, że opracowana w firmie Energoinstal SA technologia zapewnia uzyskanie wysokiej jakości połączenia spełniającego wymagania klasy „B” wg PN-EN ISO 13919.

Słowa kluczowe: spawanie laserowe, rury ożebrowane, stal austenityczna

\section{Abstract}

Finned tubes are the main component of heat exchangers, which considerably increases the heat efficiency of power systems. The use of heat exchangers constructed of welded finned tubes as preheaters, evaporators, and superheaters in e.g. gas boilers and heat recovery steam generators results in up to $300 \%$ increase in heat exchange.

Laser welding of finned tubes has hardly been studied and described in the literature. Thus, work was undertaken with the purpose of determining the effects of laser welding parameters on the structure and properties of finned tubes. Attempts at laser welding of finned tubes of type 304 and $304 \mathrm{H}$ austenitic steels were made in the Centre of Innovative Laser Technologies at Energoinstal SA. In the article, an automatic technology line equipped with a Trumpf disk laser and a technological system of tube manufacture was described.

Metallographic examination, hardness measurements, and technological fin pull-off tests were conducted in order to evaluate the quality of the laser welded joints.

The results of these tests confirmed that the technology developed by Energoinstal SA ensures obtaining high quality joints that meet the requirements of class $B$ specified in PN-EN ISO 13919.

Keywords: laser welding, finned tubes, austenitic steel

\section{Wstęp}

Cechą charakterystyczną kotłów gazowych i gazowo-parowych jest duży strumień gorących spalin, który jest doprowadzony do podgrzewaczy wody, parowników i przegrzewaczy pary [1,2]. Aby odebrać taką ilość energii wymienniki ciepła powinny charakteryzować się wysoką sprawnością. Sprawność wymiany ciepła zależy od współczynnika przewodzenia pomiędzy ścianką rury a spalinami, a tym samym od pola powierzchni rury [3]. Jednym ze sposobów zwiększenia sprawności jest zastosowanie spawanych rur ożebrowanych w wymiennikach ciepła, co wydatnie zwiększa powierzchnię wymiany ciepła, umożliwiając pełną optymalizację powierzchni ogrzewalnych kotła [4] (rys. 1a). Rury

takie stosuje się we wszystkich typach wymienników m.in. w podgrzewaczach, parownikach, przegrzewaczach oraz ekonomizerach [2] (rys. 1b).

Istnieje wiele technologii wytwarzania rur ożebrowanych. Podział tych technologii pokazano na rysunku 2. Najprostsze metody polegają na nawijaniu taśm metalowych na rurach. Metoda ta jest stosunkowo tania, jednak dzielona budowa wymiennika nie zapewnia wystarczająco dobrych warunków wymiany ciepła. Ponadto w miarę upływu czasu eksploatacji jakość połączenia spada pod wpływem rozszerzalności cieplnej oraz drgań, co skutkuje pogorszeniem sprawności cieplnej. Dlatego opracowano technologie, pozwalające wytwarzać rury o niedzielonej budowie, charakteryzujące się lepszą sprawnością cieplną (ok 2,5 razy

Dr hab. inż. Janusz Adamiec, prof. PŚı - Politechnika Śląska; mgr inż. Michał Więcek - Energoinstal S.A.; dr inż. Agata Turowska - Politechnika Śląska. 
większą w stosunku do gładkich rur i ok 1,5 razy większą w stosunku do rur z żebrem nawijanym). Spośród nich można wyróżnić dwie główne grupy technologii: przeróbkę plastyczną oraz spajanie $[5,6]$. W przypadku rur ożebrowanych przerabianych plastycznie, ograniczenie stanowi fakt, że ze względu na konieczność wywierania dużych odkształceń plastycznych, można je wytwarzać jedynie z materiałów dobrze odkształcalnych. Najczęściej produkuje się w ten sposób rury z niskim żebrem do $10 \mathrm{~mm}$ [7]. Podstawową technologią wytwarzania rur ożebrowanych na drodze przeróbki plastycznej jest walcowanie [8]. Można w ten sposób wytwarzać zarówno rury monometaliczne (integralne), jak i bimetalowe (wsad stanowią wtedy dwie rury, jedna włożona w drugą, walcowanie prowadzi się bez trzpienia).
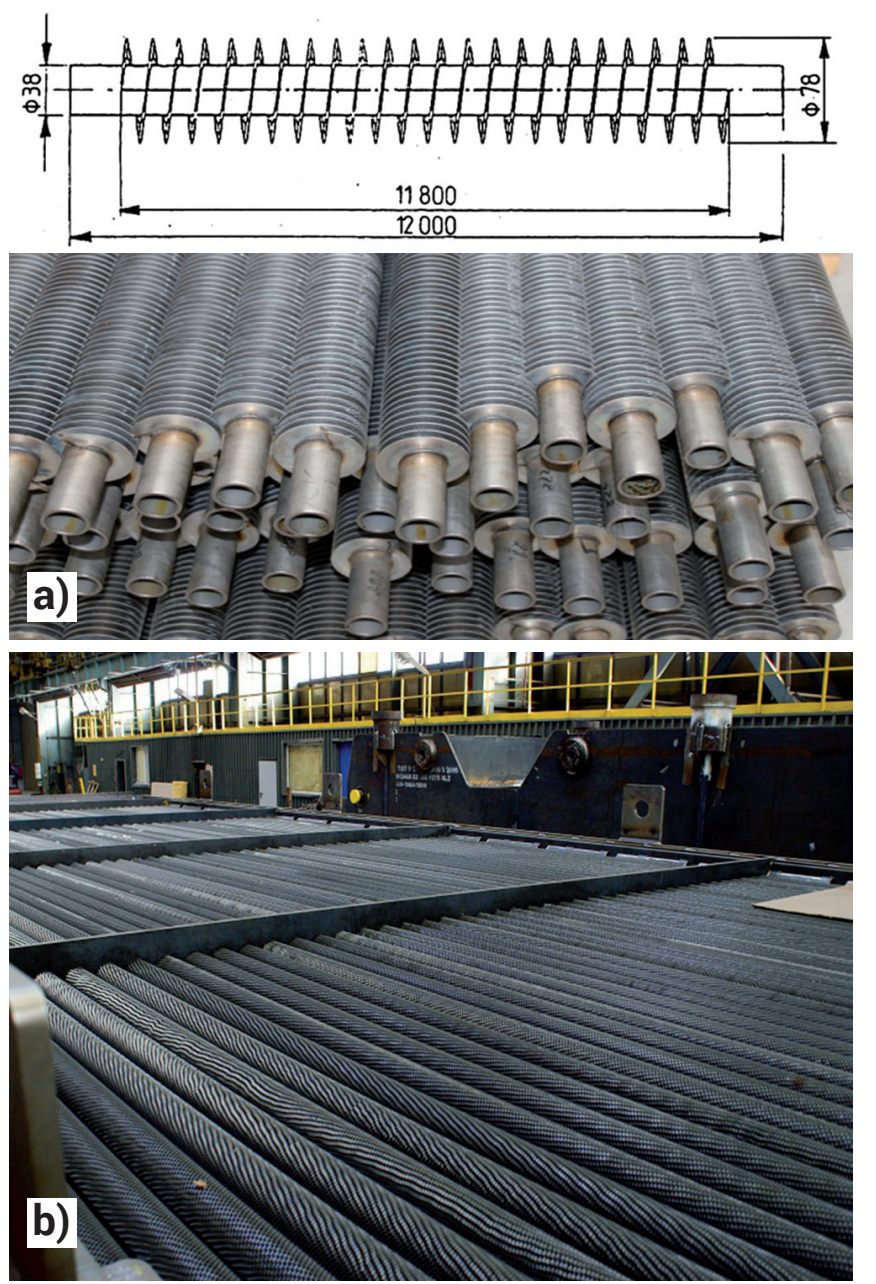

Rys. 1. Rury ożebrowane $z$ żebrem nacinany wykonane $w$ firmie Energoinstal SA (a), wymiennik ciepła zbudowany z rur ożebrowanych - parownik, kocioł Hattorf (b)

Fig. 1. Finned tubes with extruded fins manufactured by Energoinstal SA (a); heat exchanger constructed of finned tubes - boiler evaporator at Hattorf (b)

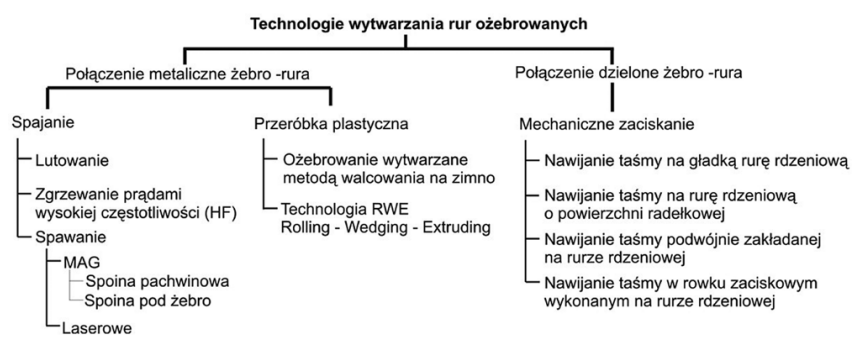

Rys. 2. Podział technologii wytwarzania rur ożebrowanych

Fig. 2. Categorization of finned tube manufacturing technologies

Technologię lutowania rur ożebrowanych opracowano w odpowiedzi na niedoskonałości rur z żebrem nawijanym, głównie obniżoną sprawność cieplną na skutek braku metalicznego połączenia między rurą a żebrem $[9,10]$. Lutowanie daje możliwość łączenia z rurą żeber o różnym kształcie i szerokim zakresie wysokości [11,2]. Często stosuje się półautomatyczny proces lutowania twardego w piecach $\mathrm{z}$ atmosferą ochronną. Kolejną technologią wytwarzania rur trwale połączonych z żebrem jest zgrzewanie prądami o dużej

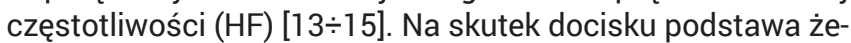
bra ulega odkształceniu, dzięki czemu powierzchnia kontaktu z rurą jest większa niż przekrój żebra. W przypadku zgrzewania żeber ciągłych mogą występować trudności związane z fałdowaniem brzegów żebra przy jego podstawie (zaburza to przepływ medium podczas eksploatacji i obniża sprawność elementu) [16]. Typową niezgodnością w tym procesie są wypryski ciekłego metalu wzdłuż obu brzegów żebra [16].

Następną technologią wytwarzania rur ożebrowanych jest spawanie. Obecnie rury ożebrowane często wykonywane są poprzez automatyczne spawanie elektrodą topliwą w osłonie gazów aktywnych (MAG) $[16,17]$. Technologia ta stosowana jest $\mathrm{w}$ dwóch wariantach. Pierwszy polega na wykonaniu spoiny pachwinowej, charakteryzuje się jednak małą wydajnością (prędkość spawania do 18 obr/min) oraz licznymi niezgodnościami spawalniczymi, głównie brakiem ciągłości spoiny i niesymetrycznością połączenia [18].

Wariant drugi polega na spawaniu pod żebro, z prędkością spawania do $60 \mathrm{obr} / \mathrm{min}$, co pozwala na ograniczenie ilości zużytego materiału dodatkowego, a także na łączenie rury z taśmą ciętą [13]. Wadą tego procesu są natomiast licznie występujące niezgodności spawalnicze, takie jak brak przetopienia, podtopienia i rozpryski [16].

Alternatywą dla technologii spawania MAG i zgrzewania HF jest spawanie laserowe. Dotychczas czynnikami ograniczającymi możliwość stosowania laserów do spawania elementów kotłów były moc wiązki, trudności związane z precyzyjnym przygotowaniem złącza, możliwość utwardzenia w spoinie i wąskiej strefie wpływu ciepła oraz podatność na pękanie gorące $[18,19]$. Spawanie laserem niesie jednak ze sobą istotne korzyści w postaci wzrostu wydajności oraz stabilności procesu. Zastosowanie urządzeń laserowych do spawania wiąże się z ich licznymi zaletami, ale również spadkiem cen laserów przy jednoczesnym wzroście niezawodności tych urządzeń oraz wzroście mocy emitowanej wiązki laserowej i jej jakości $[20,21]$.

Do wytwarzania spawanych rur ożebrowanych wykorzystuje się stale niestopowe (np. P235) i niskostopowe typu C-Mo, C-CrMo w gatunkach 15Mo3, 13CrMo4.4 i 10CrMo4.10 wg DIN 17175. W czasie realizacji projektów bloków o parametrach nadkrytycznych stwierdzono, że zakres stosowania klasycznych stali dla energetyki oraz stali martenzytycznych został wyczerpany na poziomie temperatury pracy $650{ }^{\circ} \mathrm{C}$ ze względu na spadek ich odporności na pełzanie i odporności na utlenianie. Projektowanie wyższych parametrów wylotowych pary do $720^{\circ} \mathrm{C}$ i $35 \mathrm{MPa}$ wymaga stosowania stali austenitycznych (np. Super304 H) i stopów niklu (np. Inconel 617).

Analiza danych literaturowych oraz zapotrzebowania rynku wskazuje na konieczność opracowania technologii laserowego spawania rur ożebrowanych ze stali austenitycznych oraz określenie ich właściwości użytkowych w zastosowaniach w kotłach o parametrach nadkrytycznych i ultranadkrytycznych.

\section{Materiał do badań}

Analiza stosowanych materiałów konwencjonalnych (stali żarowytrzymałych o osnowie ferrytycznej) oraz materiałów o podwyższonych właściwościach żarowytrzymałości i żaroodporności (żarowytrzymałe stale austenityczne i stopy niklu) wykazała, że materiałami o największym 
potencjale zastosowania do produkcji spawanych laserowo rur ożebrowanych są stale austenityczne w gatunkach 304 (1.4301) i 304H (1.4948)(tabl. I). Jako główne kryteria, które powinny spełniać rury ożebrowane ze stali austenitycznych stosowane w kotłach o parametrach nadkrytycznych i ultranadkrytycznych przyjęto ciągłe złącze rura-żebro z pełnym przetopieniem zapewniające prawidłową przewodność cieplną.

\section{Symulacja numeryczna procesu spawania laserowego rur ożebrowanych ze stali austenitycznych}

Celem symulacji było określenie pola temperatury, naprężeń i odkształceń podczas spawania laserowego rur ożebrowanych ze stali austenitycznych. Uzyskane dane wykorzystane zostały do opracowania wytycznych technologicznych spawania laserowego oraz oceny odkształceń spawalniczych. Symulacje wykonano przy wykorzystaniu pakietu SYSWELD ${ }^{\mathrm{TM}}$ 2014. Geometria modelu wraz z siatką elementów skończonych została przedstawiona na rysunku 3. Trójwymiarowy model składał się z 465703 elementów skończonych. W miejscach wykonywanych połączeń oraz obszarze przewidywanej strefy wpływu ciepła, siatka została zagęszczona tak, aby jak najdokładniej opisać zjawiska, które były w tym miejscu modelowane, (rys. 3b). Do symulacji spawania laserem wprowadzono cylindryczne źródło ciepła oraz przyjęto parametry spawania: moc wiązki laserowej: $2.8 \mathrm{~kW}$, prędkość spawania: $78 \mathrm{~mm} / \mathrm{s}$ (50 obr/min), sprawność procesu: $20 \%$, średnica plamki lasera: $1 \mathrm{~mm}$, współczynnik wnikania $20 \mathrm{~W} /\left(\mathrm{m}^{2}{ }^{\circ} \mathrm{C}\right)$. Zgodnie z warunkami spawania na zautomatyzowanych stanowiskach, elementy zostały utwierdzone do spawania poprzez odebranie wszystkich stopni swobody punktom siatki, na brzegu rury jak przedstawiono na rysunku 3c.
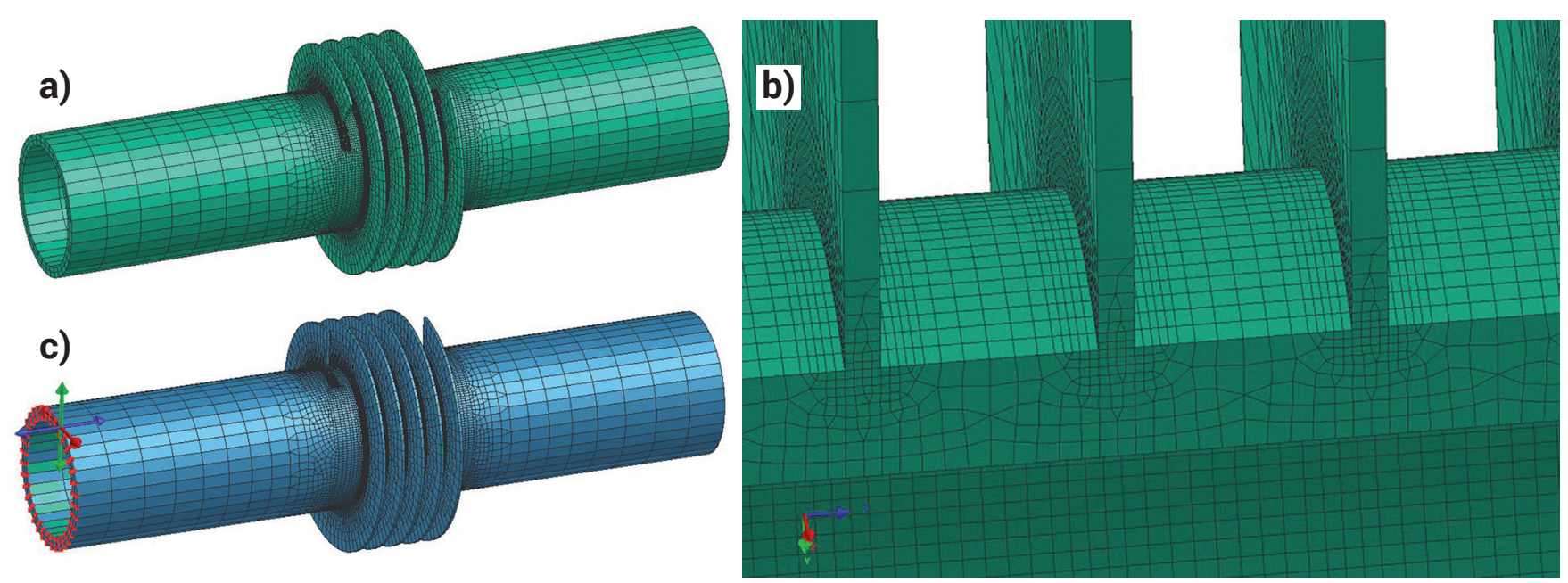

Rys. 3. Trójwymiarowy model numeryczny rury ożebrowanej (a), przekrój poprzeczny w miejscu spawania (b), model numeryczny rury ożebrowanej z zaznaczonym miejscem utwierdzenia (c)

Fig. 3. Three-dimensional numerical model of a finned tube (a), cross-section of the joint (b), numerical model of a finned tube with the place of attachment marked (c)

Tablica VII. Wymiary geometryczne i ocena wizualna złączy różnoimiennych wykonanych w procesie lutospawania łukowego metodą CBT Table VII. Geometrical dimensions and visual assessment of CBT arc braze welded dissimilar joints

\begin{tabular}{|c|c|c|c|c|c|c|c|c|c|c|c|}
\hline \multicolumn{12}{|c|}{ Skład chemiczny stali 304H wykorzystanej do produkcji rury ożebrowanej [\%] } \\
\hline Wytop & \multirow{2}{*}{ Rura } & C & $\mathrm{Mn}$ & $\mathrm{Si}$ & $\mathrm{P}$ & $S$ & $\mathrm{Ni}$ & $\mathrm{Cr}$ & $\mathrm{N}$ & Mo & Sn \\
\hline QP290 & & 0,046 & 1,77 & 0,38 & 0,025 & 0,006 & 8,96 & 18,22 & 0,075 & 0,23 & 0,006 \\
\hline \multirow{2}{*}{$\begin{array}{c}\text { Wytop } \\
885496\end{array}$} & \multirow{2}{*}{ Bednarka } & C & $\mathrm{Mn}$ & Si & $\mathrm{P}$ & S & $\mathrm{Ni}$ & $\mathrm{Cr}$ & $\mathrm{N}$ & \multicolumn{2}{|c|}{$\mathrm{Ti}$} \\
\hline & & 0,04 & 1,27 & 0,41 & 0,025 & 0,002 & 8,05 & 18,26 & 0,052 & \multicolumn{2}{|c|}{-} \\
\hline \multicolumn{12}{|c|}{ Skład chemiczny według normy EN 10216/5-2004 stali 304H [\%] } \\
\hline C & $\mathrm{Mn}$ & Si & $\mathrm{P}$ & $\mathrm{S}$ & \multicolumn{2}{|c|}{$\mathrm{Ni}$} & \multicolumn{2}{|l|}{$\mathrm{Cr}$} & $\mathrm{N}$ & \multicolumn{2}{|c|}{$\mathrm{Ti}$} \\
\hline $0,04 \div 0,0$ & $\leq 2,0$ & $\leq 1$ & & $\leq 0,015$ & 8,00 & & $17,0 \div 19,0$ & & 11 & - & \\
\hline & & Skład cl & czny s & ali 304 w & korzystar & ej do pro & kcji rury & ebrowa & [\%] & & \\
\hline Wytop & Dur & $\mathrm{C}$ & $\mathrm{Mn}$ & Si & $\mathrm{P}$ & $\mathrm{S}$ & $\mathrm{Ni}$ & $\mathrm{Cr}$ & $\mathrm{N}$ & & i \\
\hline 44279 & nura & 0,014 & 1,66 & 0,33 & 0,024 & 0,001 & 10,19 & 18,26 & 0,069 & & - \\
\hline Wytop & & $\mathrm{C}$ & $\mathrm{Mn}$ & $\mathrm{Si}$ & $\mathrm{P}$ & S & $\mathrm{Ni}$ & $\mathrm{Cr}$ & $\mathrm{N}$ & & i \\
\hline 26003 & Bednarka & 0,023 & 1,34 & 0,31 & 0,031 & 0,005 & 8 & 18,07 & 0,064 & & 01 \\
\hline & & & I chemi & ny wedł & normy & $\mathrm{N} 10216$ & $-2004 \mathrm{st}$ & 304 [\%] & & & \\
\hline $\mathrm{C}$ & $\mathrm{Mn}$ & Si & $\mathrm{P}$ & $S$ & $\mathrm{Ni}$ & & & $\mathrm{N}$ & & $\mathrm{Ti}$ & \\
\hline$\leq 0,03$ & $\leq 2,0$ & $\leq 1$ & $\leq 0,04$ & $\leq 0,03$ & $8,00 \div 10$ & 17 & $-19,5$ & $\leq 0,11$ & & - & \\
\hline
\end{tabular}


$\mathrm{Na}$ rysunkach $4 \mathrm{a}$ i $4 \mathrm{~b}$ przedstawione zostały rozkłady pól temperatur wokół jeziorka ciekłego metalu w trakcie spawania oraz na przekrojach poprzecznych rury. Analiza numeryczna prowadzona była do momentu wystygnięcia elementu spawanego do temperatury otoczenia $\left(20^{\circ} \mathrm{C}\right)$. Na rysunkach 4c i 4d przedstawiono rozkłady naprężeń zredukowanych, a na rysunkach $4 \mathrm{e}$ i $4 \mathrm{f}$ rozkład odkształceń po ostygnięciu do temperatury otoczenia.

Analiza pola temperatury podczas spawania laserowego wskazuje, że rozkład ten jest równomierny, co skutkuje mniejszymi naprężeniami i odkształceniami podczas spawania
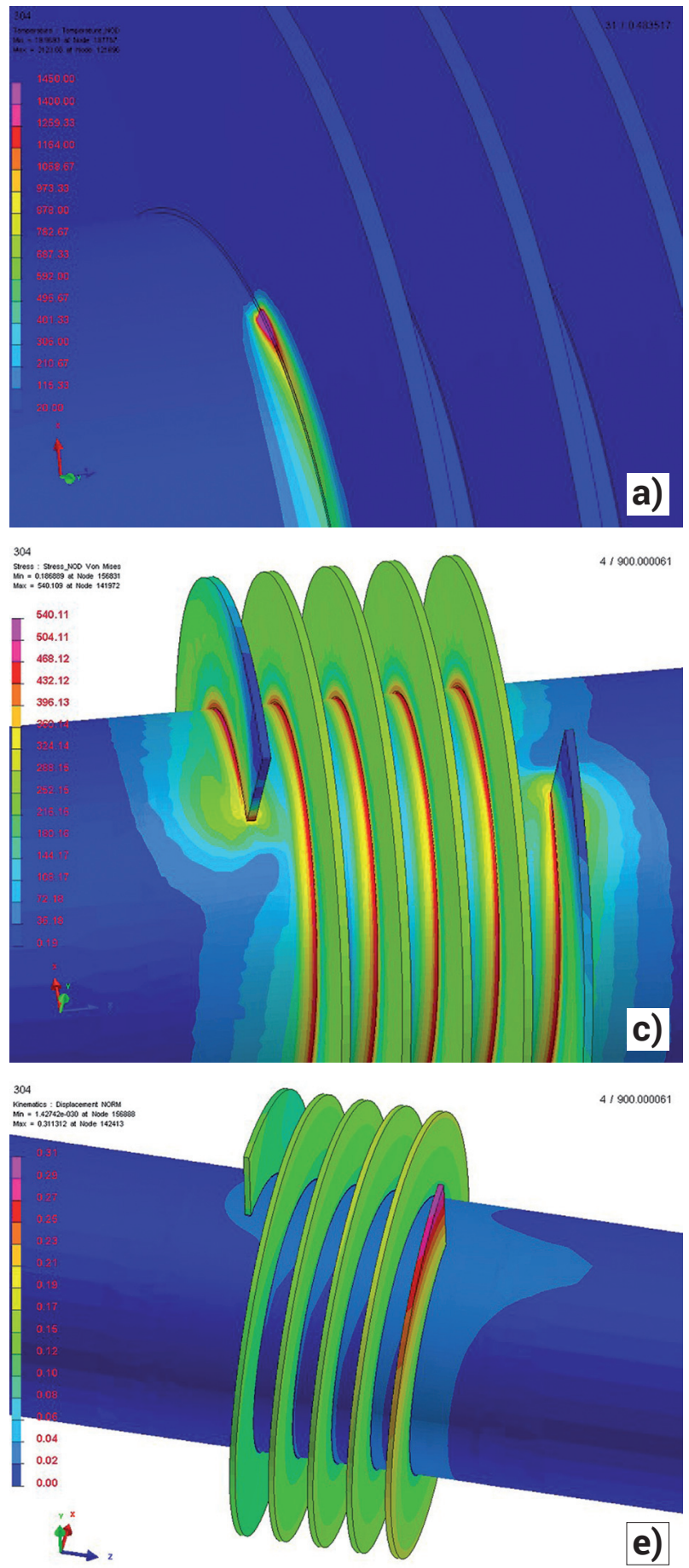

w stosunku do spawania metodą MAG (rys. 4a i 4b) [22]. Po zakończeniu spawania laserowego rur ożebrowanych ze stali austenitycznych największe naprężenia (wytężenie całkowite wg hipotezy Von Misesa) występują w obszarze spoiny i obszarze bezpośrednio przyległym do niej (rys. 4c i 4d). Wartość naprężeń była w zakresie 450 $\div 540 \mathrm{MPa}$, co jest wartością mniejszą od wytrzymałości stali ok. $R_{m}=540-750 \mathrm{MPa}$. Maksymalne odkształcenie plastyczne w obszarze spoiny i SWC nie przekracza wartości 12\% (rys. 4e i 4f). Odkształcenie elementów spawanych dotyczy głównie spawanego żebra i wynosi maksymalnie ok. 0,31 mm na analizowanym odcinku połączenia.
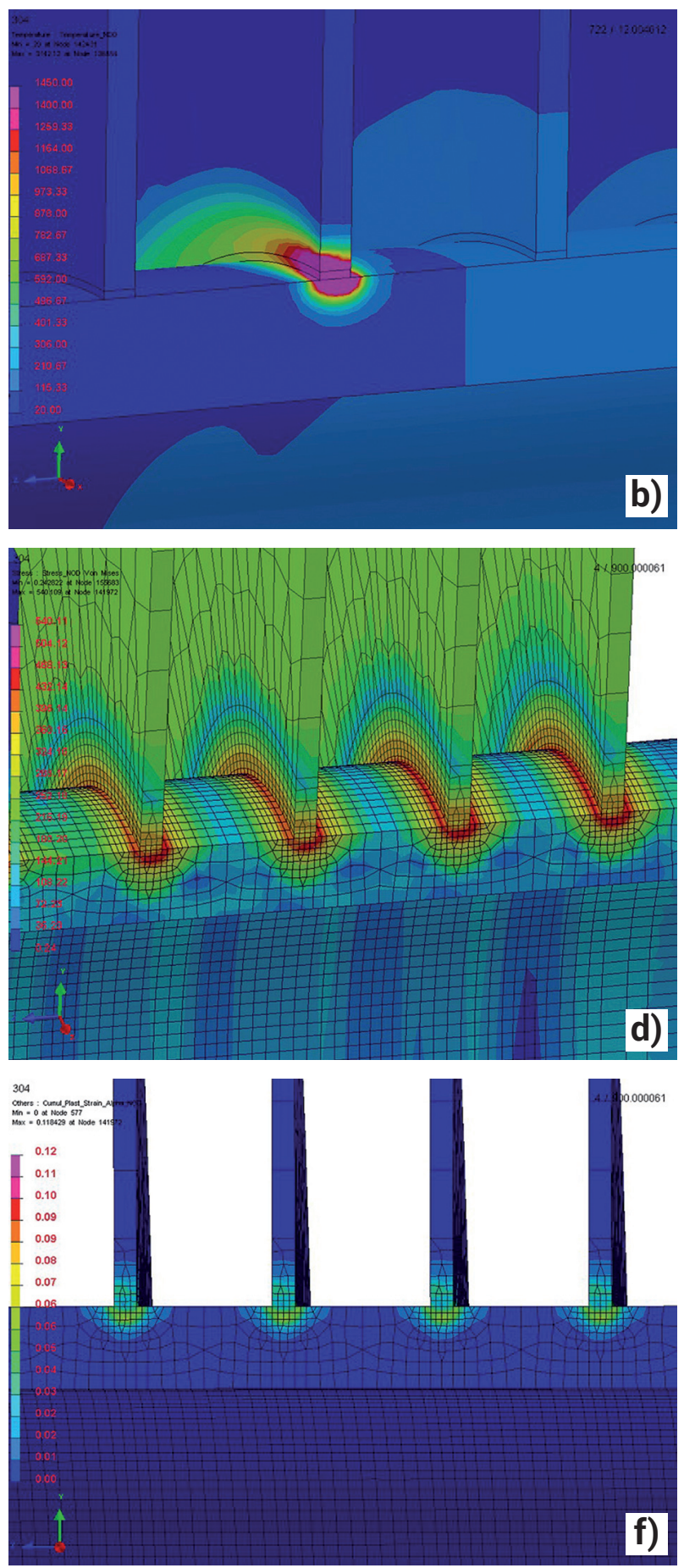

Rys. 4. Wyniki symulacji numerycznej (MES) spawania laserowego rury ożebrowanej ze stali austenitycznej: a) rozkład temperatury w jeziorku ciekłego metalu w trakcie procesu spawania, b) rozkład temperatury na przekroju poprzecznym w jeziorku ciekłego metalu w trakcie procesu spawania czwartego żebra c) rozkład naprężeń zredukowanych Von Misesa na powierzchni spawanej rury ożebrowanej po ostygnięciu do temperatury otoczenia d) rozkład naprężeń zredukowanych Von Misesa na przekroju poprzecznym spawanej rury ożebrowanej po ostygnięciu do temperatury otoczenia, e) odkształcenie całkowite żebra, f) rozkład odkształceń na przekroju rury ożebrowanej

Fig. 4. Results of numerical simulation (MES) of laser welding of a finned tube of austenitic steel: a) distribution of temperature in the molten weld pool during welding, b) distribution of temperature over the cross section of the joint during the welding of the fourth fin; c) distribution of von Mises uniaxial stress on the surface of a welded finned tube after cooling down to the ambient temperature; d) distribution of von Mises uniaxial stress on the cross-section of a welded finned tube after cooling down to the ambient temperature, e) total fin deformation, f) deformation distribution over the cross section of a finned tube. 


\section{Próby technologiczne spawania laserowego rur ożebrowanych ze stali austenitycznych}

Próby technologiczne spawania laserowego przeprowadzono na automatycznym stanowisku do spawania rur ożebrowanych opracowanym w Energoinstalu SA. Stanowisko składa się z lasera dyskowego TRUDISK 8002 firmy Trumph z układem podziału wiązki laserowej na dwa stanowiska spawalnicze wyposażone w systemy obrotu i posuwu rur podczas spawania oraz automatyczny system malowania. Schematycznie układ spawania pokazano na rysunku 5.

Laser TRUDISK 8002 został wyposażony w dwa światłowody od długości $30 \mathrm{~m}$, co w połączeniu z dwoma głowicami spawalniczymi umożliwia spawanie przemienne na każdej z linii stanowiska. Taki układ powoduje maksymalizacje czasu pracy lasera. Podczas spawania na pierwszej linii, na drugiej linii trwa przygotowanie następnej rury. Układ transportu rur umożliwia ich przemieszczanie z prędkością liniową do $5 \mathrm{~m} / \mathrm{min}$ oraz przy prędkości obrotowej rury $350 \mathrm{obr}$./min. Zakres długości spawanych rur to od 3 do $24 \mathrm{~m}$, przy zachowaniu wybiegów od 50 do $250 \mathrm{~mm}$.

Istotnym czynnikiem decydującym o możliwości spawania rur ożebrowanych z prędkością obrotową powyżej 100 obr/min. jest układ pozycjonowania głowicy spawającej. Zaprojektowany został układ trójosiowy z płynną regulacją w każdej osi dzięki czemu uzyskano możliwość dokładnej regulacji położenia głowicy laserowej, automatycznego sczepiania taśmy przed rozpoczęciem procesu spawania oraz automatycznego odcinania taśmy wiązką laserową po zakończeniu procesu spawania. W celu podgrzewania rur przed spawaniem opracowano system indukcyjnego podgrzewania rur, który w stosunku do podgrzewania gazowego pozwala na pełna regulację i kontrolę temperatury podgrzewania wstępnego. System ten jest zintegrowany z całą linią i umożliwia nagrzewanie rury o średnicy 44,5 i grubości ścianki $5 \mathrm{~mm}$ do temperatury $300{ }^{\circ} \mathrm{C}$ przy prędkości liniowej posuwu 5m/min [19].

Próby spawania rur ożebrowanych ze stali austenitycznych 304 i 304H przeprowadzono w Energoinstal SA w Centrum Innowacyjnych Technologii Laserowych. Parametry technologiczne procesu spawania laserowego zestawiono w tablicy II. Do osłony obszaru spawania stosowano argon o przepływie $5 \mathrm{I} / \mathrm{min}$. Jako kryterium jakości złącza przyjęto poziom jakości „B” wg PN-EN ISO 13919. Wykonano rury ożebrowane o średnicy $48,3 \times 2,77 \mathrm{~mm}$ z żebrem ciągłym o szerokości $1 \mathrm{~mm}$ i wysokości $15 \mathrm{~mm}$. Odległość między wynosiła żebrami $6,25 \mathrm{~mm}$. Przykładowe rury ożebrowane ze stali 304 i $304 \mathrm{H}$ pokazano na rysunku 6.

Przeprowadzone badania wizualne zgodnie $z$ wymaganiami EN ISO 17637, nie wykazały niezgodności powierzchniowych oraz niezgodności kształtu spoiny wg PN-EN ISO 13919 (poz. 2, tabl. II dla stali 304 i poz. 3, tabl. II dla stali 304H). Stwierdzono, że istnieje możliwość wykonania prawidłowej spoiny z pełnym przetopieniem na całej długości, co gwarantuje prawidłowy odbiór ciepła podczas eksploatacji. Na tej podstawie zakwalifikowano złącze do poziomu jakości „B”.

\section{Ocena struktury i właściwości połączenia rura - żebro wykonanego laserem ze stali austenitycznych 304 i 304H}

Do badań metalograficznych próbki wycięte równolegle do osi rury były szlifowane i polerowane w celu przygotowania zgładu metalograficznego. Strukturę złącza ujawniono w procesie trawienia elektrolitycznego. Badania metalograficzne
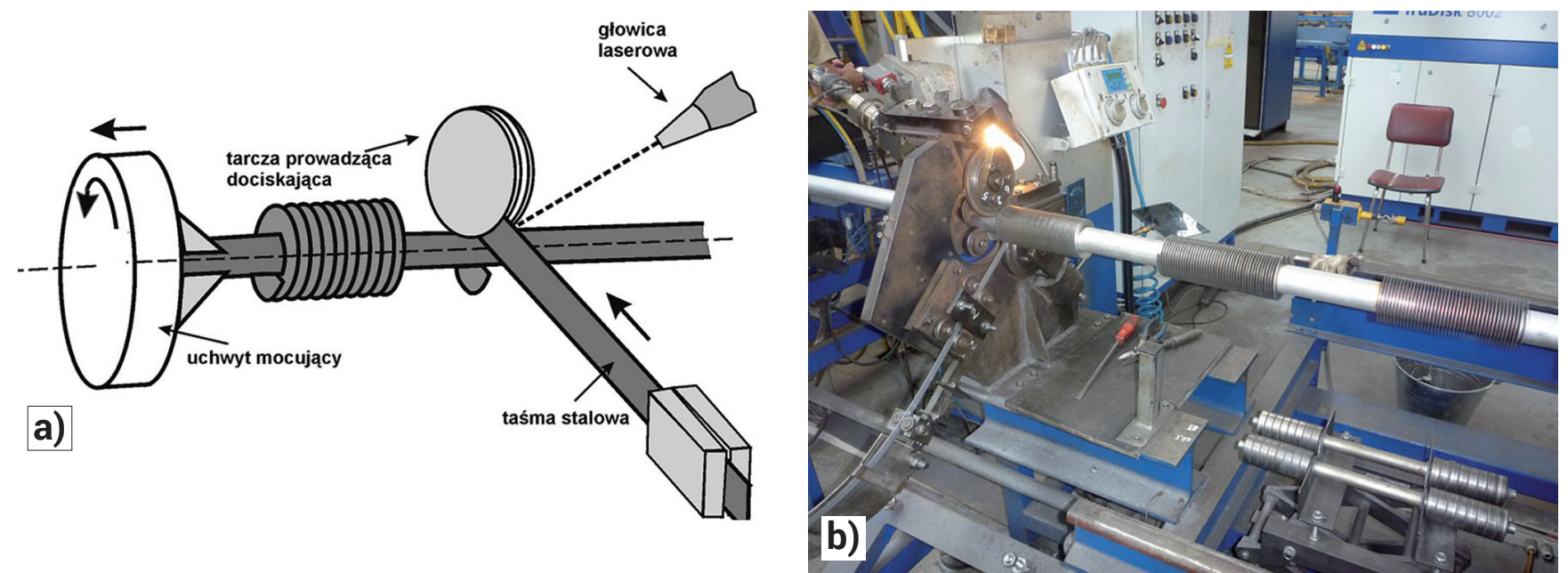

Rys. 5. Laserowe stanowisko do spawania rur ożebrowanych opracowane w Energoinstalu SA: a) schemat ogólny układu spawania [19], b) spawanie laserowe rur

Fig. 5. Workstation for laser welding of finned tubes designed in Energoinstal SA: a) general diagram of the welding system [19], b) laser welding of tubes

Tablica II. Parametry spawania rur ożebrowanych ze stali austenitycznej 304 i 304H

Table II. Welding parameters for finned tubes of type 304 and $304 \mathrm{H}$ austenitic steels

\begin{tabular}{|c|c|c|c|c|c|}
\hline $\begin{array}{c}\text { moc wiązki } \\
{[\mathrm{kW}]}\end{array}$ & $\begin{array}{c}\text { Prędkość } \\
\text { obrotwa [n/min] }\end{array}$ & $\begin{array}{c}\text { prędkość } \\
\text { liniowa [m/s] }\end{array}$ & $\begin{array}{c}\text { posuw } \\
{[\mathrm{mm}]}\end{array}$ & $\begin{array}{c}\text { liczba żeber } \\
{[1 / \mathrm{m}]}\end{array}$ & Uwagi \\
\hline 3,4 & 60 & 0,10 & 5,8 & 160 & zbyt duże wtopienie - stal 304, 304H \\
\hline 3,2 & 50 & 0,083 & 5,8 & 160 & $\begin{array}{c}\text { prawidłowe wtopienie - stal 304 } \\
\text { zbyt duże wtopienie - stal 304H }\end{array}$ \\
\hline 2,8 & 40 & 0,067 & 5,8 & 160 & $\begin{array}{c}\text { Brak pełnego przetopienia - stal 304 } \\
\text { prawidłowe wtopienie - stal 304H }\end{array}$ \\
\hline
\end{tabular}


wykonano na mikroskopie świetlnym Olympus GX71 w technice pola jasnego przy powiększeniach od 50x do 500x. Przykładowe struktury połączenia pokazano na rysunku 7.

Przeprowadzona analiza wyników badań metalograficznych ujawniła trzy typowe obszary charakterystyczne dla złączy spawanych ze stali austenitycznych (rys. 7). Stwierdzono, że zarówno rura jak i żebro są zbudowane z poligonalnych ziaren austenitu w układzie pasmowym charakterystycznym dla procesu walcowania rur oraz taśmy. Na linii wtopienia zarówno w stali 304, jak i stali 304H obserwuje się strefę niepełnego stopienia (SNS), w której następuje nadtopienie ziaren roztworu stałego i krystalizacja epitaksjalna kryształów spoiny (rys. 7b i 7d). Obszar spoiny składa się z wydłużonych ziaren austenitu, które narastają zgodnie z kierunkiem odprowadzenia ciepła podczas spawania (rys. 7b i 7d). Nie ujawniono pęknięć, pęcherzy lub innych niezgodności strukturalnych, co pozwala na stwierdzenie że mikrostruktura złącza laserowego jest prawidłowa i pozwala na zakwalifikowanie go na poziomie jakości „B” wg PN-EN ISO 13919, zarówno dla rur ze stali 304, jak również dla rur ze stali $304 \mathrm{H}$.
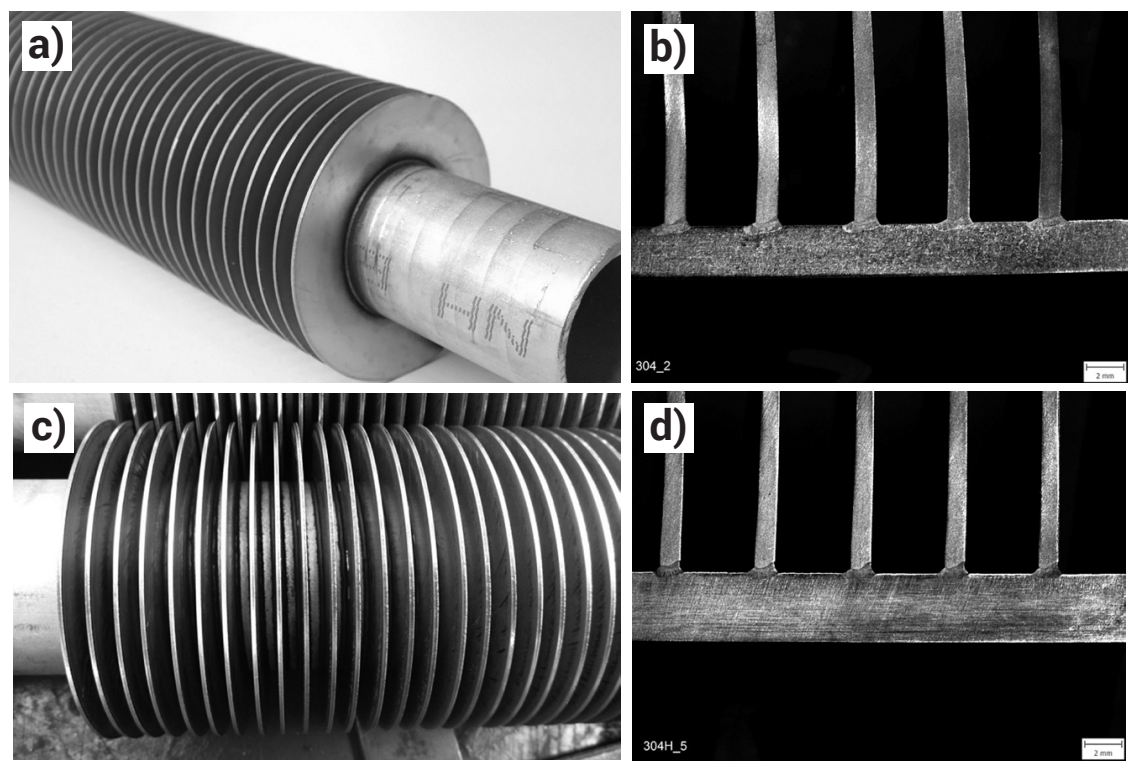

Rys. 6. Rury ożebrowane spawane laserowo ze stali austenitycznych w Energoinstal S.A.: a) widok ogólny rura ze stali $304 ;$ b) makrostruktura połączenia rura-żebro (stal 304), moc wiązki 2,8 kW, poz. 3, Tabl. II.; c) rura ze stali $304 \mathrm{H}$; d) makrostruktura połączenia rura-żebro, moc wiązki $3,2 \mathrm{~kW}$, poz. 2, Tabl. II

Fig. 6. Laser welded finned tubes of austenitic steels by Energoinstal S.A.: a) general view: tube of type 304 steel; b) macrostructure of the tube-fin joint (type 304), laser beam power 2.8 $\mathrm{kW}$, Table II, item 3; c) tube of type $304 \mathrm{H}$ steel; d) macrostructure of the tube-fin joint, laser beam power $3.2 \mathrm{~kW}$, Table II, item 2
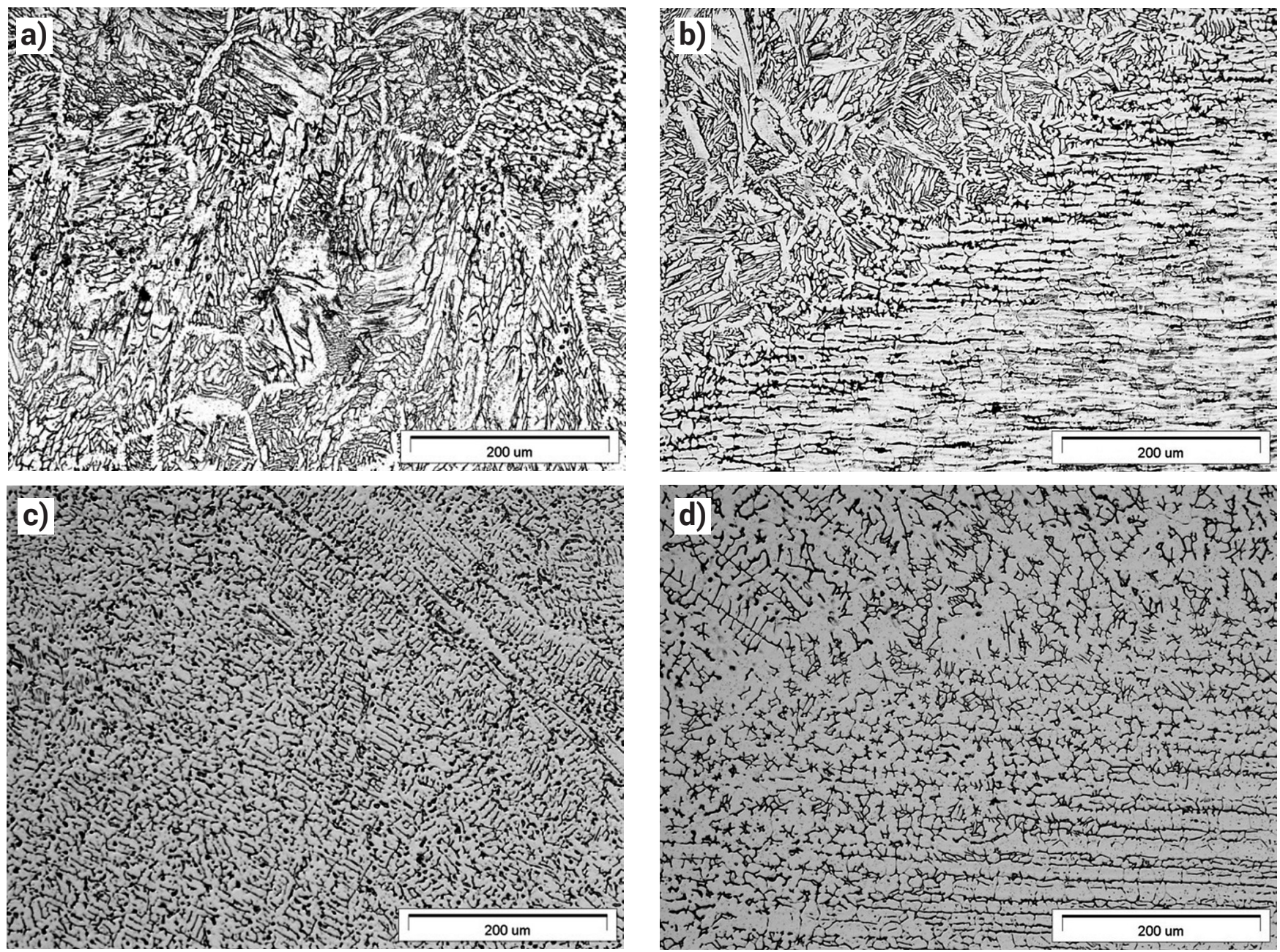

Rys. 7. Mikrostruktura złącza spawanego laserem rury ożebrowanej ze stali austenitycznych: a) struktura spoiny - stal 304, b) linia wtopienia od strony płaskownika - stal 304, c) struktura spoiny - stal 304H, b) linia wtopienia od strony płaskownika - stal 304H

Fig. 7. Microstructure of laser welded joints of finned tubes of austenitic steels: a) weld structure - Type 304 steel, b) weld line on the side of the flat bar - type 304 steel, c) weld structure - type $304 \mathrm{H}$ steel, b) weld line on the side of the flat bar - type $304 \mathrm{H}$ steel 
Uzupełnieniem badań były pomiary twardości metodą Vickersa przy obciążeniu 9,8 N (HV1) zgodnie z EN 1043-1 oraz próba technologiczna odrywania żebra w próbie statycznego rozciągania. Wyniki pomiarów twardości pokazano na rysunku 8, natomiast na rysunku 9 pokazano przykładowe próbki po próbie zerwania połączenia laserowego rura-żebro ze stali 304.

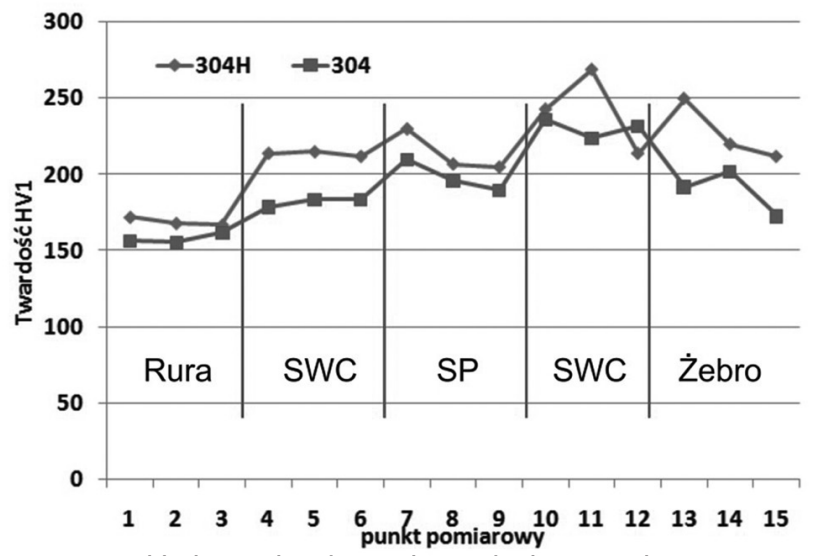

Rys. 8. Rozkład twardości w połączeniach rura-żebro spawanych laserowo ze stali austenitycznych

Fig. 8. Hardness distribution in laser welded tube-fin joints of austenitic steels
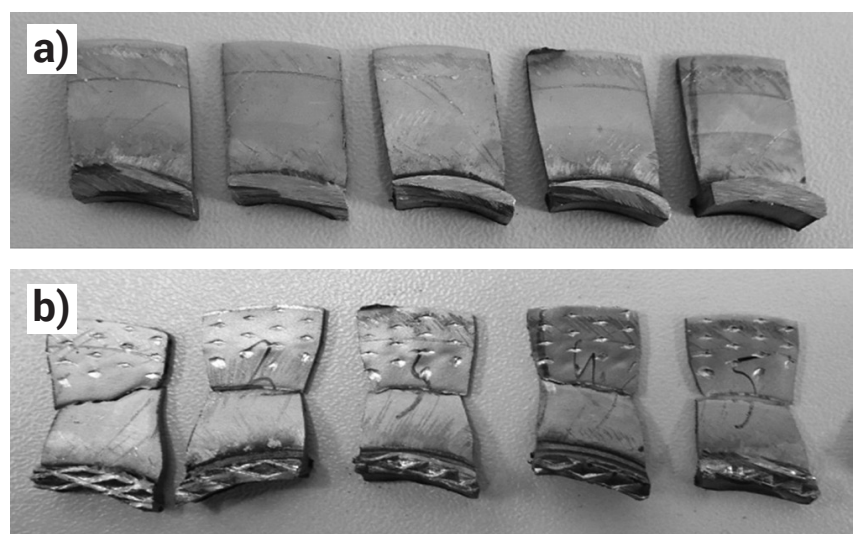

Rys. 9. Wyniki próby technologicznej rozciągania statycznego połączenia rura-żebro ze stali 304: a) próbki do badań wycięte z rury ożebrowanej spawanej laserowo, b) miejsce zerwania połączenia - zerwanie poza złączem

Fig. 9. Results of a technological static tensile test of a tube-fin joint of type 304 steel: a) test specimens cut out from a laser welded finned tube, b) place of joint fracture - fracture outside the welded joint

Analiza wyników rozkładu twardości nie ujawniła utwardzenia w złączach stali 304 i 304H (rys. 8). Stwierdzono, że twardość żebra ze stali 304 jest na poziomie $180 \mathrm{HV}$, w strefie wpływu ciepła od strony żebra średnia twardość wynosi $230 \mathrm{HV}$, w spoinie $199 \mathrm{HV}$, podobnie w SWC od strony rury - $182 \mathrm{HV}$ a twardość materiału rodzimego rury wynosiła $158 \mathrm{HV}$ (rys. 8). Nieznacznie wyższe twardości zmierzono w złaczu spawanym laserowo stali 304H. Średnia twardość żebra wynosiła 230HV, w strefie wpływu ciepła twardość była na poziomie $242 \mathrm{HV}$, w spoinie wynosiła $214 \mathrm{HV}$, podobnie jak w SWC od strony rury - $214 \mathrm{HV}$ a materiał rury charakteryzował się twardością 169HV (rys. 8).

Technologiczna próba statycznego rozciągania złącza rura-żebro (odrywania żebra) była wykonywana w Energoinstalu S.A. w celu porównania wytrzymałości połączenia z wytrzymałością materiału rodzimego. Do próby przygotowywano fragmenty złącza żebra z rurą, które było wycinane prostopadle do osi rury. Próby rozciągania była wykonana na maszynie wytrzymałościowej firmy Cometech w uchwytach, które umożliwiają sztywne zamocowanie złącza rura-żebra. Przykładowe próbki przed rozciąganiem pokazano na rysunku 9a, natomiast na rysunku 9b pokazano próbki ze stali 304 po zerwaniu. Stwierdzono, że we wszystkich badanych połączeniach zarówno ze stali 304, jak również stali 304H zerwanie nastąpiło poza złączem. Na tej podstawie stwierdzono, że wytrzymałość złącza spawanego laserowo rur-żebro ze stali austenitycznych jest większa od wytrzymałości żebra.

\section{Podsumowanie}

Czynnikami decydującymi o sprawności cieplnej spawanych rur ożebrowanych, rozumianej jako stosunek strumienia ciepła przechodzącego przez rurę z żebrem do strumienia ciepła przechodzącego przez rurę gładką jest technologia spawania, która powinna zapewnić złącze spawane z pełnym przetopieniem, bez niezgodności spawalniczych, a w szczególności bez nieciągłości spoiny [3,4,23].

Analiza danych literaturowych potwierdza, że wybór technologii oraz dokładność wykonania złącza ma istotny wpływ na wartość oporu kontaktu złącza, który może powodować obniżenie współczynnika wnikania ciepła o $20 \%$ [24]. Potwierdzają to również wyniki badań Stephana [25], który stwierdził, że brak połączenia żebra z rurą $\mathrm{w}$ wielu miejscach, na krótkich odcinkach ma mniejszy wpływ na sprawność wymiany ciepła rury ożebrowanej, niż nieciągłość połączenia na długich odcinkach. W pracy [3] wykazano, że typowe niezgodności kształtu spoiny pachwinowej wykonanej metodą MAG oraz niezgodności złączy występujące przy łączeniu taśmy obniżają sprawność cieplną spawanych rur ożebrowanych nie więcej niż o $10 \%$ w stosunku do rur ożebrowanych bez niezgodności spawalniczych, natomiast nieciągłości w złączu lub niepełne przetopienie spoiny powodują wzrost oporu kontaktu i tym samym znaczące obniżenie sprawności cieplnej rur ożebrowanych (rys. 10), np. dla nieciągłości spoiny na poziomie $50 \%$ sprawność cieplna spada do 0,8, a dla spoiny w której przetopienie jest tylko 20\% sprawność obniża się do 0,65 (rys. 10).

Na tej podstawie stwierdzono, że opracowana nowa technologia spawania laserowego rur ożebrowanych ze stali austenitycznych powinna zapewniać złącze z pełnym przetopieniem na całej długości rury.

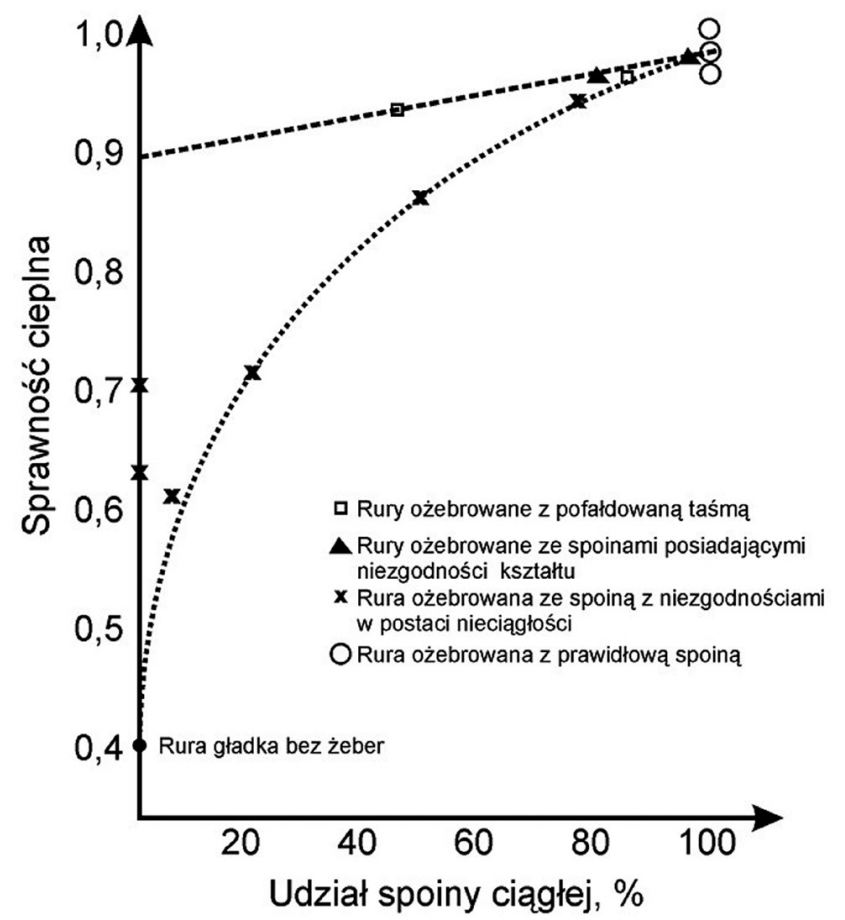

Rys. 10. Zależność sprawności cieplnej rury ożebrowanej od jakości wykonania połączenia taśma-rura [3]

Fig. 10. Correlation between the heat efficiency of a finned tube and the quality of the tube-strip bond [3] 
Przeprowadzono próby spawania laserowego rur ożebrowanych ze stali austenitycznych w gatunku $304 \mathrm{i} 304 \mathrm{H}$. Próby wykonano na zautomatyzowanej linii w Energoinstal S.A., wyposażonej w laser dyskowy o mocy 8 kW firmy Trumph (rys. 5). Na podstawie wyników badań wizualnych oraz badań makrostrukturalnych rur ożebrowanych ze stali 304 i 304H stwierdzono, że połączenie charakteryzuje pełnym przetopieniem na całej długości rury (rys. 6). Mikrostruktura materiału rodzimego składa się z poligonalnych ziaren austenitu (rys. 7a i 7c). Na linii wtopienia ujawniono strefę niepełnego stopienia z charakterystycznymi nadtopieniami granic ziaren austenitu, szczególnie od strony żebra (rys. 6b i 7d). W strefie tej na nadtopionych ziarnach krystalizują epitaksjalnie kryształy spoiny, które następnie narastają w formie kolumnowej w kierunku osi spoiny (rys. 6b i 6d). Pomiary twardości nie wykazały utwardzenia materiału złącza (rys. 8). Potwierdzeniem wysokich właściwości wykonanych złączy są wyniki technologicznej próby rozciągania (odrywania żebra). Zerwanie próbek nastąpiło we wszystkich przypadkach w materiale żebra, poza złączem (rys. 9).

Uzyskane wyniki wskazują, że wykonane złącza spełniają wymagania poziomu jakości „B” wg PN-EN ISO 13919, co stanowi podstawę do kwalifikowania technologii spawania wg PN EN ISO 15614-11.

\section{Literatura}

[1] Janzen J., Schiemann M., Braun H.: Effiziente Dampfkesselanlagen fur industrielle Heiz- und Heizkraftwerke sowie Hilfskesselanlagen fur Kraftwerke, Wolfgang Sobbe, VGB Powertech 7/2011.

[2] Mizielińska K., Olszak J.: Parowe źródła ciepła, WNT 2009.

[3] Adamiec P., Ochman J., Polubniok H. Voss W.: Wpływ wadliwości rur ożebrowanych na ich sprawność termiczną, Nowe technologie i materiały w metalurgii i inżynierii materiałowej, II Seminarium Naukowe Wydział Inżynierii Materiałowej i Metalurgii, Politechnika Śląska, Katowice 2004.

[4] Adamiec P. Voss W., Wąs D.: Spawanie zespołów kotłów przemysłowych metodą MAG w osłonie mieszanek gazowych, Materiały seminarium: Korzyści i kryteria zastosowania mieszanek spawalniczych oraz drutów proszkowych, Instytut Spawalnictwa, Gliwice 1997.

[5] Stopyra M, Adamiec J.: Technologie wytwarzania rur ożebrowanych, Materiały konferencyjne: XLI Szkoła Inżynierii Materiałowej, AGH, Kraków 2013.

[6] Kocurek R., Adamiec J.: Manufacturing technologies of finned tubes, Advances In Materials Science, Vol. 13, No. 3 (37), September 2013.

[7] Mitrovic J.: Heat Exchanger and Condenser Tubes, Tube Types - Materials - Attributes - Machning. Publico Publications 2004.

[8] Pasierb A.: Nowe rozwiązania w technologii walcowania rur żebrowanych. Rudy i Metale Nieżelazne, nr 10-11 s. 505507, 2002.

[9] Jannick P., Meurer C., Swidersky H.: Potential of brazed finned tube heat exchangers in comparison to mechanically produced finned tube exchangers, 9th International Refrigeration Conference at Purdue, 2002.

[10] US Patent No 2807074: Manufacturing of brazed fin tube and the like, 1957.
[11] http://www.boilerroom.com/econinfo.html (28.07.2013)

[12] http://www.tex-fin.com/custom.html (28.07.2013)

[13] GEA Opole - informacje technologiczne.

[14] http://www.rosink.bilfinger.com/en/products-and-services/ fintube-division/helically-finned-tubes/noh-welded-u-fins/ (28.07.2013)

[15] http://www.lbltrading.com/suppliers/spirogills/spiro-gillsfin-tubing-brochure.pdf (28.07.2013)

[16] US Patent No 5343015 A: Laser assisted high frequency weIding (1994).

[17] Adamiec J. Gawrysiuk W. Więcek M.: Spawanie rur ożebrowanych laserem światłowodowym, Przegląd spawalnictwa 11 (2009), s. 82-86.

[18] Gawrysiuk W., Adamiec J., Więcek M.: Możliwości spawania laserowego i hybrydowego ścian szczelnych oraz rur ożebrowanych, Konferencja Spawanie w Energetyce, Opole Jarmołtówek 2008.

[19] http://citl.energoinstal.pl/pl-PL/hala_i_laser.html (28.07.2013)

[20] Stano S.: Lasery YAG w zrobotyzowanych stanowiskach spawalniczych, Materiał Seminarum „Rozwój spawania i cięcia laserem CO2 i YAG oraz możliwości wykorzystania" Instytut Spawalnictwa, 2005.

[21] Industrial Laser Solutions, IPG Photonics, 2005.

[22] Adamiec J., Więcek M., Kokot G.: Technologia spawania laserowego rur ożebrowanych., Przegląd Spawalnictwa 5/2014, s. 3-9.

[23] Chmielniak T.: Technologie Energetyczne, Wydawnictwo Politechniki Śląskiej, Gliwice 2004.

[24] Hobler T.: Ruch ciepła i wymienniki, WNT Warszawa 1974.

[25] Stepan K.: Kaltechniki-Klimatisierung 1996.

Praca sfinansowana w ramach Programu Badań Stosowanych finansowanego przez Narodowe Centrum Badań i Rozwoju, projekt pt.: "Technologia spawania laserem rur ożebrowanych ze stali austenitycznych $i$ stopów niklu przeznaczonych do pracy w kotłach o parametrach nadkrytycznych i ultranadkrytycznych.", nr umowy PBS1/A5/13/2012. 